Article

\title{
Phosphate Leaching from Green Roof Substrates-Can Green Roofs Pollute Urban Water Bodies?
}

\author{
Agnieszka Karczmarczyk*, Agnieszka Bus and Anna Baryła \\ Faculty of Civil and Environmental Engineering, Department of Environmental Improvement, \\ Warsaw University of Life Sciences-SGGW, Nowoursynowska 166, 02-787 Warsaw, Poland; \\ agnieszka_bus@sggw.pl (A.Bu.); anna_baryla@sggw.pl (A.Ba.) \\ * Correspondence: agnieszka_karczmarczyk@sggw.pl
}

Received: 29 November 2017; Accepted: 8 February 2018; Published: 13 February 2018

\begin{abstract}
Green roofs are an effective stormwater measure due to high water retention capacity and the ability of delaying stormwater runoff. However, low importance is still given to the pollutant leaching potential of substrates used in green roof construction. The aim of the study is to estimate the concentrations and loads of $\mathrm{P}-\mathrm{PO}_{4}{ }^{3-}$ in runoff from extensive and intensive substrates. To achieve this goal, several commonly-used fresh substrates were analyzed for $\mathrm{P}_{-} \mathrm{PO}_{4}{ }^{3-}$ leaching potential in different scale experiments, from laboratory batch tests, leaching column experiments, and long-term monitoring of open air green roof containers. The results of the study confirmed that fresh green roof substrates contain phosphorus in significant amounts of $17-145 \mathrm{mg} \cdot \mathrm{P}-\mathrm{PO}_{4}{ }^{3-} / \mathrm{kg}$ and, thus, can contribute to eutrophication of freshwater ecosystems. High correlation between phosphate content estimated by $\mathrm{HCl}$ extraction and cumulative load in leachate tests suggests that the batch $\mathrm{HCl}$ extraction test can be recommended for the comparison and selection of substrates with low potential $\mathrm{P}$ leaching. Volume-weighted mean concentrations and UALs of $\mathrm{P}-\mathrm{PO}_{4}{ }^{3-}$ leaching from fresh substrates were higher in cases of intensive substrates, but there was no clear relationship between substrate type and the observed $\mathrm{P}_{-} \mathrm{PO}_{4}{ }^{3-}$ concentration range. To avoid increasing eutrophication of urban receivers the implementation of $\mathrm{P}$ reduction measures is strongly recommended.
\end{abstract}

Keywords: phosphorus; green roofs; substrates; eutrophication; urban water bodies

\section{Introduction}

Green roof substrates are an artificial mixture of compounds designed to provide proper conditions for plant growth and rainwater retention. The discussion if they are a source or sink of runoff pollutants is still active [1]. Among other pollutants, phosphorus (P) is almost universally found in higher concentrations in green roof leachate than in runoff from conventional roofs $[2,3]$. Widespread application of green roof technology could, therefore, lead to increases in P levels entering urban waterways [2].

Most green roof substrates are a mixtures of mineral and organic compounds. The most popular mineral components are: clay, sand, volcanic materials, crushed brick, and expanded lightweight materials, and among organic components, the most popular are: compost and peat [4]. Compost typically has very high P content. Buffam and Mitchell [5] obtained the value of leachable phosphate of above $200 \mathrm{mg} \cdot \mathrm{P}-\mathrm{PO}_{4}{ }^{3-} / \mathrm{kg}$ in deionized water extract. Toland et al. [6] reported that SRP concentrations in runoff from green roofs with compost were more than 10 times greater than SRP concentrations without compost added. Organic components of the substrate have often been suggested as a source of P-PO ${ }_{4}{ }^{3-}$ to green roof runoff (e.g., [7]). Growing media with $50 \%$ to $60 \%$ organic matter had the highest leachate concentrations of phosphorus [8]. Organic matter included in the substrate is beneficial for 
plant growth, but when it decomposes it may leach nutrients [9]. It was stated that the addition of $10 \%$ organic matter is optimal for the substrate and plants, and organic matter exceeding $25 \%$ is not recommended for extensive green roofs [10]. Often practice in green roof substrate preparation is the integration of slow-release inorganic fertilizers [8,11]. Malcolm et al. [12] suggested to decrease fertilizer use during installation in order to reduce the negative impacts on water quality during the first few years. Organic matter content and fertilizers are well described sources of phosphorus, however, mineral components, e.g., commonly used crushed red brick, sand, or gravel can also be a significant sources of phosphorus in green roof runoff [4].

Phosphorus in vegetated roof runoff appears mainly in phosphate form $[13,14]$, and $\mathrm{P}_{-} \mathrm{PO}_{4}{ }^{3-}$ concentrations vary from low, e.g., $0.003-0.079 \mathrm{mg} \cdot \mathrm{P}-\mathrm{PO}_{4}{ }^{3-} / \mathrm{L}$ [15] or $0.006-0.012 \mathrm{mg} \cdot \mathrm{P}^{-\mathrm{PO}_{4}}{ }^{3-} / \mathrm{L}$ [16] to medium, e.g., $0.27-0.37 \mathrm{mg} \cdot \mathrm{P}-\mathrm{PO}_{4}{ }^{3-} / \mathrm{L}$ [17] or high (above $1 \mathrm{mg} \cdot \mathrm{P}-\mathrm{PO}_{4}{ }^{3-} / \mathrm{L}$ ) (e.g., [18-21]). Due to increasing problems with stormwater management in urban areas, the total area of green roofs is going to rise in the future [22,23]. Extensive green roofs have thin substrate layers and need little maintenance, while intensive green roofs have thicker substrates and require more maintenance [24]. Intensive green roofs can accommodate various plant types, while on extensive green roofs plant selection is limited [25]. Substrates are usually designed to retain rain water and support plant growth, whereas nutrient retention is still of low importance. Most of substrates used in green roof construction are potential sources of $\mathrm{P}$ in runoff, and the difference can lay in the amount of $\mathrm{P}$ released. Substrate composition, depth, age, fertilizer use, plant species and coverage, local air quality, and the intensity of precipitation events are the factors shaping P runoff from green roofs $[4,14]$.

The goals of this study were: (i) to confirm that green roof substrates are a significant source of P-PO ${ }_{4}{ }^{3-}$ in runoff; (ii) to estimate the concentrations and loads of $\mathrm{P}_{-} \mathrm{PO}_{4}{ }^{3-}$ leaching from extensive and intensive substrates; and (iii) to demonstrate the necessity of implementation of P-protection measures to limit green roofs' contributions to eutrophication of urban water bodies.

\section{Materials and Methods}

\subsection{Materials}

Five green roof substrates collected from a local market were named as $\mathrm{S}$, followed by a number (S1-S5). S1-S3 (intensive type) and S5 (extensive type) are fresh substrates sampled from the newly-constructed green roofs or from large bags before implementation. S1 is an intensive substrate predicted for lawns or small shrubs. It consists of lightweight aggregates, mineral aggregates, sand, compost, low peat, and it was fertilized before application. S4 is a growing medium sampled from the fresh prefabricated Sedum mate (Xelo Flor moss-sedum-herbs XF317). Substrates S1-S3 are mixtures of mineral and organic compounds, while S5 is a 100\% mineral mixture of crushed red brick, gravel, lime, and sand. For the substrates S2-S3 we were not able to obtain specifications, we only obtained the manufacturer's warranty that they are FLL (Forschungsgesellschaft Landschaftsentwicklung Landschaftsbau) [26] or DAFA (Stowarzyszenie Wykonawców Dachów Płaskich i Fasad) [27] compliant. Substrate S6 used in long-term experiments consisted of washed sand, chalcedonite, clay, low peat, and compost. It is an intensive type of substrate for use in multi-layered green roof systems. The characteristics of the tested substrates are set in Table 1. 
Table 1. Characteristics of substrates used in the study.

\begin{tabular}{cccccccc}
\hline Substrate & S1 & S2 & S3 & S4 & S5 & S6 (2013) & S6 (2017) \\
\hline type & intensive & intensive & intensive & extensive & extensive & intensive & intensive \\
\hline age & fresh & fresh & fresh & fresh & fresh & fresh & 5 years old \\
\hline composition & mineral-organic & mineral-organic & mineral-organic & no data & mineral & mineral-organic & mineral-organic \\
\hline $\mathrm{pH}$ & 7.31 & 7.19 & 7.60 & 8.03 & 7.74 & - & - \\
\hline $\begin{array}{c}\text { OM content } \\
{[\%]}\end{array}$ & 10.4 & 7.0 & 7.4 & 7.2 & 0 & - & - \\
\hline $\begin{array}{c}\text { bulk density } \\
{\left[\mathrm{kg} / \mathrm{m}^{3}\right]}\end{array}$ & 1054.8 & 1051.1 & 983.4 & 1145.6 & 1498.7 & $1430.0-1570.0$ & $1560.0-1755.0$ \\
\hline
\end{tabular}

\subsection{Methods}

\subsubsection{Extraction (Batch Test)}

Leachable phosphates: triplicate samples of dried substrates were placed in an extractor vessel made of inert material and distilled water, and were agitated for $24 \mathrm{~h}$ at $135 \mathrm{rpm}$ at room temperature. Phosphorus content: samples of dried substrates were placed in a vessel and a quantity of $1 \mathrm{nHCl}$ equal to two times the weight of the solid phase was added. Agitation time and environment were similar to water extraction.

For $\mathrm{pH}, \mathrm{PN}-\mathrm{ISO}$ standard was used [28], which specifies an instrumental method for the routine determination of $\mathrm{pH}$ using a glass electrode in a 1:5 $(v / v)$ suspension of soil in water. The $\mathrm{pH}$ was measured by a Volcraft PH-212 meter. Organic matter (OM) content (\%) was determined using the loss of ignition at $550{ }^{\circ} \mathrm{C}$.

\subsubsection{Leaching (Column) Experiment}

Five columns of a diameter of $144 \mathrm{~mm}$ were filled with substrates S1-S5, as described in Section 2.1. The thickness of each substrate was $4 \mathrm{~cm}$, regardless the type of the substrate. The use of different thicknesses for intensive and extensive substrates would change the retention capacity and thus, reduce the volume of the outflow, and make the results of the experiment difficult to compare. All columns were watered before the experiment. Then the substrates were irrigated with tap water for 90 days, in doses and a schedule developed on the basis of the precipitation observed at a nearby meteorological station $\left(52^{\circ} 16^{\prime} 07.16^{\prime \prime} \mathrm{N}, 21^{\circ} 04^{\prime} 89.84^{\prime \prime} \mathrm{E}\right)$ in 2013 . Within the time of the leaching test, $470 \mathrm{~mm}$ of water was supplied to each column, which is the value similar to natural rainfall observed in the vegetation period in the open air long-term experiment. The volume of leachate was measured manually after each simulated precipitation. The cumulative load of the $\mathrm{P}_{-} \mathrm{PO}_{4}{ }^{3-}$ supplied with the tap water and discharged from the substrates was calculated based on volumes of irrigation rates, leachate volumes, and $\mathrm{P}-\mathrm{PO}_{4}{ }^{3-}$ concentrations.

\subsubsection{Long-Term Green Roof Monitoring (Open Air Experiment)}

The green roof substrate (intensive type, S6) was placed in plastic container of dimensions of $0.5 \times 0.3 \times 0.3 \mathrm{~m}$ (length, width, height) in early spring, 2013. The substrate had a thickness of $17 \mathrm{~cm}$ and was underlined with the drainage layer made of washed gravel with a thickness of $8 \mathrm{~cm}$ and Polyfelt TS 20 filtration geomembrane. From April 2013 to May 2015, a bare substrate was tested, but due to the occurrence of colonizers, from June 2015 Sedum plants obtained from the dismantled full-scale nine year-old green roof were introduced to the container. No fertilizers were applied to the green roof during construction, nor the monitoring period. Plant cover in years 2015-2017 were not well developed due to the lack of irrigation and fertilization (Figure 1), therefore, the role of plants was not discussed in this study. 

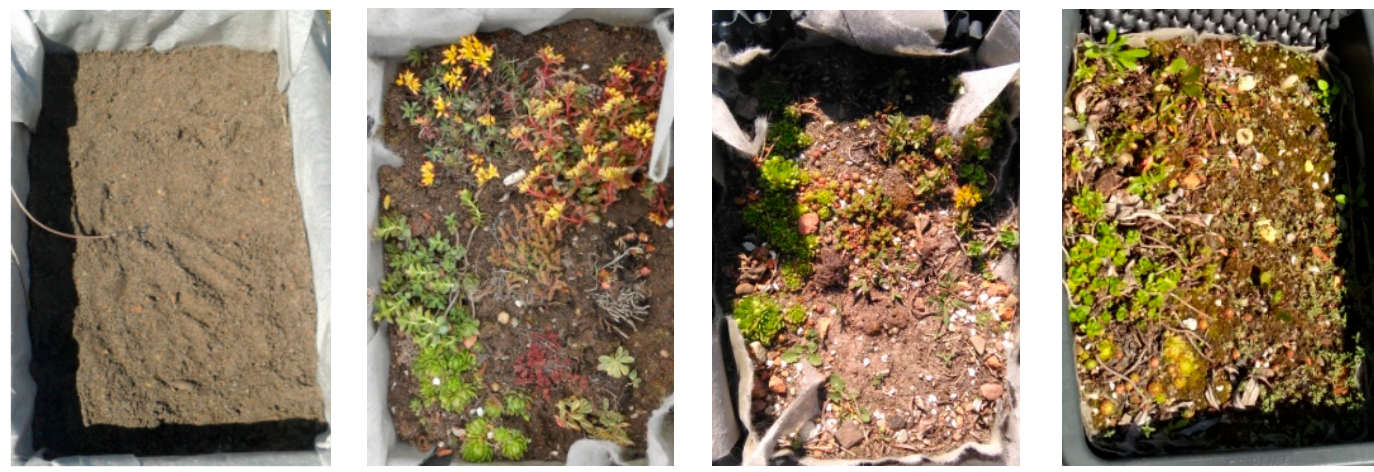

Figure 1. Long-term open air green roof experiment. Photos (from the left): first year (2013) — bare substrate; June 2015—model planted with Sedum plants; images from 2016 to 2017 (fifth year)—shows poor development of plant cover.

The precipitation data for monitoring period were obtained from a nearby meteorological station $\left(52^{\circ} 16^{\prime} 07.16^{\prime \prime} \mathrm{N}, 21^{\circ} 04^{\prime} 89.84^{\prime \prime} \mathrm{E}\right)$. Leachates from the model were collected in tanks and sampled after each precipitation event. The measurement of the volumes of the leachates and sampling were made manually. In this study the results from the first, second, and fifth year of monitoring of $\mathrm{P}-\mathrm{PO}_{4}$ leaching from green roof substrates are presented. The third year of the experiment (2015) was very dry. No precipitation occurred in April-May, and the total precipitation in the vegetation period was lower than $190 \mathrm{~mm}$. That was the reason why leachates were not collected and can explain poor plant development on the substrate. The monitoring period of the green roof container in 2016 covered the months from August to December and, thus, could not be included in the comparison of green roof performance in the vegetation periods.

All extracts, samples of tap water, rainwater, and leachates collected from the column experiment and open air models were filtered and analyzed for $\mathrm{P}_{-} \mathrm{PO}_{4}{ }^{3-}$ on a FiaStar analyzer by the ammonium molybdate method in the range of $0.005-1 \mathrm{mg} / \mathrm{L}$. All $\mathrm{P}_{-} \mathrm{PO}_{4}{ }^{3-}$ loads obtained from the above tests were recalculated to unit loads and expressed in $\mathrm{mg}$ per $\mathrm{m}^{2}$ as unit area load (UAL) to make the results of this study comparable with other studies. As in some samples of rainwater and leachates no phosphates were detected, the volume-weighted mean concentration $\left(\mathrm{C}_{\mathrm{vw}}\right)$ was used to characterize rainfall and leachates. The volume-weighted mean concentration was calculated using:

$$
\mathrm{C}_{\mathrm{vw}}=\Sigma_{\mathrm{i}=1}^{\mathrm{n}}\left(\mathrm{V}_{\mathrm{i}} \cdot \mathrm{C}_{\mathrm{i}}\right) / \Sigma_{\mathrm{i}=1}^{\mathrm{n}}\left(\mathrm{V}_{\mathrm{i}}\right)
$$

where $\mathrm{Vi}=$ total volume of runoff measured for event $\mathrm{i}(\mathrm{L}) ; \mathrm{Ci}=$ concentration of the pollutant for event i (mg/L).

The unit area load (UAL) is the total load divided by the green roof area $\left(\mathrm{mg} / \mathrm{m}^{2}\right)$, and was calculated using the following equation:

$$
\mathrm{UAL}=\Sigma_{\mathrm{i}=1}^{\mathrm{n}_{1}}\left(\mathrm{~V}_{\mathrm{i}} \cdot \mathrm{C}_{\mathrm{i}}\right) / \mathrm{A}
$$

where $\mathrm{A}=$ area of green roof $\left(\mathrm{m}^{2}\right) ; \mathrm{Vi}$ and $\mathrm{Ci}$ as described above. For statistical analyzes Statgraphics Centurion XVI software was used.

\section{Results}

\subsection{Extraction}

Leachable phosphate content of all tested substrates were low and varied between 0.1 (S6) and 6.7 (S2) $\mathrm{mg} \cdot \mathrm{P}-\mathrm{PO}_{4}{ }^{3-} / \mathrm{kg}$ (Figure 2). However, total phosphate content in substrates was significant. In general, higher phosphate content was noted for mixtures of mineral and organic compounds (S1-S3 
and S6 fresh) than in case of mineral substrate (S5) and Sedum mat growing medium (S4). Intensive substrates (S1-S3 and S6 fresh) were characterized by higher phosphorus content than extensive substrates. Fresh substrate S6 used in open air experiments had four times higher P content than the same substrate after five years of being used, which was the result of phosphate leaching due to precipitation. There was no significant correlation found between total $\mathrm{P}_{-} \mathrm{PO}_{4}{ }^{3-}$ content $(\mathrm{mg} / \mathrm{kg})$ extracted by using hydrochloric acid $(\mathrm{HCl})$ and leachable $\mathrm{P}_{-} \mathrm{PO}_{4}{ }^{3-}$ extracted by using distilled water $\left(\mathrm{H}_{2} \mathrm{O}\right)(p<0.005)$.
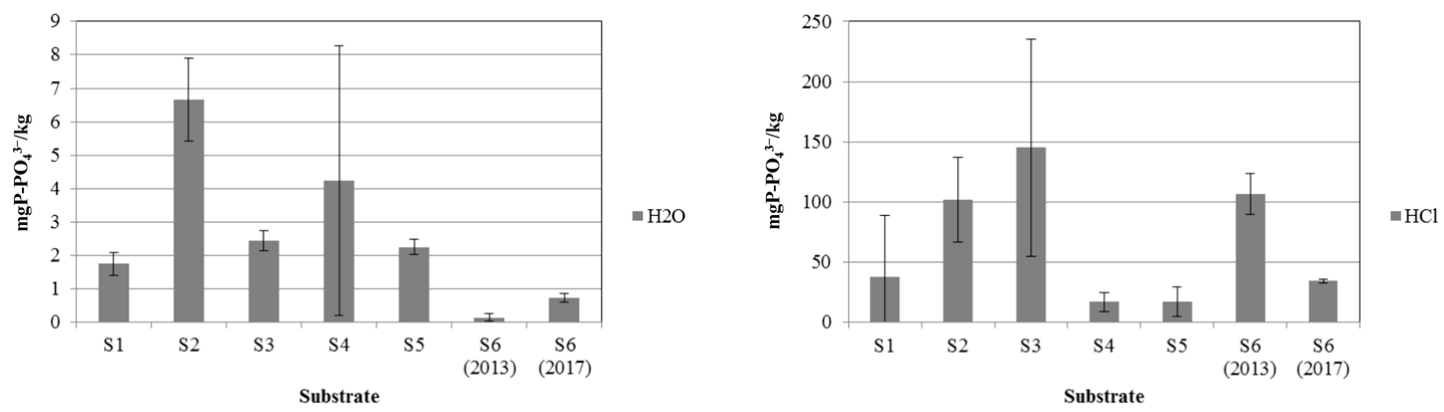

Figure 2. Total $\mathrm{P}_{-} \mathrm{PO}_{4}{ }^{3-}$ content $(\mathrm{mg} / \mathrm{kg})$ in substrates extracted by using hydrochloric acid $(\mathrm{HCl})$ and leachable $\mathrm{P}_{-} \mathrm{PO}_{4}{ }^{3-}$ extracted by using distilled water $\left(\mathrm{H}_{2} \mathrm{O}\right)$ in the batch test (mean value and standard deviation).

\subsection{Leaching Test (Column Experiment)}

Within 90 days of the leaching test, $470 \mathrm{~mm}$ of tap water was supplied in the form of simulated precipitation to each column (Table 2), which was the value similar to the natural rainfall observed in the vegetation period in the open air long-term experiment (see Section 3.3). Within this period, 44 precipitation events were simulated of which 11 were polluted with phosphates. Phosphates occurred also in tap water, as they are added as corrosion inhibitors in some water supply networks and its concentration is not limited in drinking water [23,29-31]. The volume-weighted mean concentration of $\mathrm{P}_{-} \mathrm{PO}_{4}{ }^{3-}$ in the simulated precipitation was $0.035 \mathrm{mg} \cdot \mathrm{P}-\mathrm{PO}_{4}{ }^{3-} / \mathrm{L}$ (Table 2). In most cases observed phosphate concentrations were low, with the exceptions on day 21,34, and 38, when the concentrations of $0.339,0.943$, and $0.207 \mathrm{mg} \cdot \mathrm{P}-\mathrm{PO}_{4}{ }^{3-} / \mathrm{L}$ were noted, respectively (Figure 3 ).

Table 2. Experimental data of column leaching experiment.

\begin{tabular}{|c|c|c|c|c|c|}
\hline \multicolumn{6}{|c|}{ Rainfall } \\
\hline Precipitation [mm] & & & 470.0 & & \\
\hline $\begin{array}{l}\text { Concentration of } \mathrm{P}_{-} \mathrm{PO}_{4}{ }^{3-}[\mathrm{mg} / \mathrm{L}] \text { in } \\
\text { rainwater samples: mean }{ }^{*}(\mathrm{~min}-\max )\end{array}$ & & & $0.035(0-0.943)$ & & \\
\hline $\begin{array}{l}\mathrm{UAL} \text { of } \mathrm{P}^{-\mathrm{PO}_{4}{ }^{3-}}\left[\mathrm{mg} / \mathrm{m}^{2}\right] \text { in } \\
\text { precipitation }\end{array}$ & & & 16.644 & & \\
\hline \multicolumn{6}{|c|}{ Runoff } \\
\hline Substrate & S1 & S2 & S3 & $\mathrm{S} 4$ & S5 \\
\hline Volume of leachate [mm] & 330.7 & 308.3 & 323.9 & 308.8 & 346.5 \\
\hline $\begin{array}{l}\text { Concentration of } \mathrm{P}-\mathrm{PO}_{4}{ }^{3-}[\mathrm{mg} / \mathrm{L}] \text { in } \\
\text { leachate samples: mean }{ }^{*}(\mathrm{~min}-\mathrm{max})\end{array}$ & $0.116(0-0.769)$ & $0.242(0-0.791)$ & $0.286(0-3.169)$ & $0.050(0-0.961)$ & $0.060(0-0.974)$ \\
\hline $\begin{array}{l}\text { UAL of } \mathrm{P}-\mathrm{PO}_{4}{ }^{3-}\left[\mathrm{mg} / \mathrm{m}^{2} \text { of }\right. \\
\text { substrate }]\end{array}$ & 37.6 & 73.2 & 90.8 & 15.1 & 20.4 \\
\hline $\begin{array}{c}\text { Unit load of } \mathrm{P}^{-\mathrm{PO}_{4}{ }^{3-}}[\mathrm{mg} / \mathrm{kg} \text { of } \\
\text { substrate] }\end{array}$ & 0.908 & 1.773 & 2.351 & 0.337 & 0.346 \\
\hline
\end{tabular}



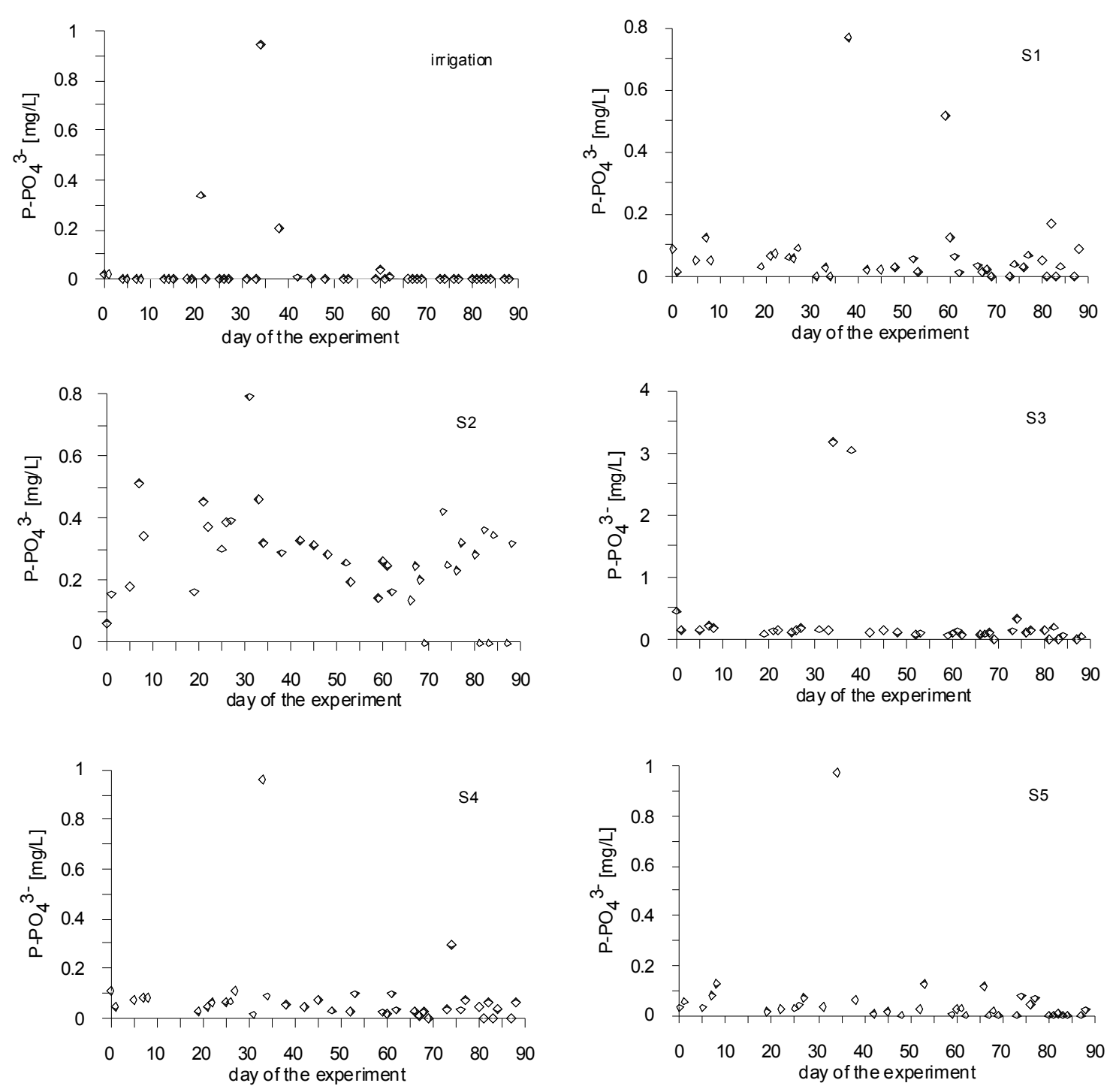

Figure 3. Concentrations of $\mathrm{P}-\mathrm{PO}_{4}{ }^{3-}$ in simulated precipitation and leachates from substrates tested in the column experiment.

Phosphates were detected in most leachates from all tested substrates (Figure 3). The volume-weighted mean concentration of $\mathrm{P}_{-}-\mathrm{PO}_{4}{ }^{3-}$ in leachates ranged from $0.050 \mathrm{mg} \cdot \mathrm{P}-\mathrm{PO}_{4}{ }^{3-} / \mathrm{L}$ (S4) to $0.286 \mathrm{mg} \cdot \mathrm{P}-\mathrm{PO}_{4}{ }^{3-} / \mathrm{L}$ (S3) (Table 2). Phosphate concentrations in leachates from most of the columns were not significantly correlated with the volumes of precipitation, volumes of leachate, or the concentration of phosphates in simulated precipitation (Table 3).

The UAL of phosphate supplied to tested substrates with simulated precipitation amounted $16.644 \mathrm{mg} / \mathrm{m}^{2}$ and was lower than the UALs in leachates from all substrates except, Sedum plant-growing medium (S4). That means that both intensive- and extensive-type green roof substrates were the source of phosphorus and could potentially contribute to eutrophication of freshwater ecosystems. Cumulative load of phosphorus leached from the substrates during the time of experiment varied from 0.337 to $2.351 \mathrm{mg} / \mathrm{kg}$ (Table 2). Intensive substrates (S1-3) released more phosphates than extensive (mineral) substrate (S5), which was not a significant source of $\mathrm{P}_{-} \mathrm{PO}_{4}{ }^{3-}$ if compared with the amount of $\mathrm{P}-\mathrm{PO}_{4}{ }^{3-}$ supplied. 
Table 3. Results of correlation analyses between phosphate concentrations in leachate S1-S5 and the volumes of precipitation, volumes of leachate, and concentration of phosphates, presented as Pearson correlation coefficient $r$ and probability $p$ (in brackets). $p$-values below 0.05 indicate statistically significant non-zero correlations at the $95.0 \%$ confidence level.

\begin{tabular}{cccc}
\hline $\begin{array}{c}\text { Concentration of } \\
\text { Phosphates in Leachate }\end{array}$ & Volume of Precipitation & Volume of Leachate & $\begin{array}{c}\text { Concentration of Phosphates in } \\
\text { Simulated Precipitation }\end{array}$ \\
\hline S1 & $0.3218(0.0332)$ & $0.2935(0.0531)$ & $0.1034(0.5041)$ \\
S2 & $-0.0643(0.6784)$ & $0.0139(0.9286)$ & $0.1742(0.2580)$ \\
S3 & $0.0484(0.7551)$ & $0.0737(0.6347)$ & $0.7847(0.0000)$ \\
S4 & $-0.1059(0.4938)$ & $-0.1004(0.5168)$ & $0.0068(0.9651)$ \\
S5 & $0.0519(0.7441)$ & $0.0238(0.8810)$ & $0.9543(0.0000)$ \\
\hline
\end{tabular}

\subsection{Long-Term Open Air Green Roof Container Monitoring}

Over the entire monitoring period, covering vegetation seasons 2013 (first year), 2014 (second year), and 2017 (fifth year), the green roof container received rainfall from $338.1 \mathrm{~mm}$ to $539.6 \mathrm{~mm}$, while runoff volumes ranged from 106.8 to $158.7 \mathrm{~mm}$ (Table 4). The green roof model retained $64.6 \%$ to $80.2 \%$ of the precipitation. The volume-weighted mean concentration of $\mathrm{P}-\mathrm{PO}_{4}{ }^{3-}$ in the precipitation in the first two years of monitoring were lower than the concentrations observed in the green roof runoff, but it was opposite in the fifth year of the observation period. The range of the observed $\mathrm{P}-\mathrm{PO}_{4}{ }^{3-}$ concentrations in precipitation and the runoff from the green roof model over the entire monitoring period was similar (Table 4).

Table 4. Experimental data of long-term open air green roof monitoring.

\begin{tabular}{|c|c|c|c|}
\hline Year & 2013 (1st Year) & 2014 (2nd Year) & 2017 (5th Year) \\
\hline Observation period [months] & IV-IX & IV-VIII & IV-IX \\
\hline \multicolumn{4}{|c|}{ Rainfall } \\
\hline Precipitation [mm] & $448.9^{* *}$ & $338.1 * *$ & 539.6 \\
\hline $\begin{array}{l}\text { Concentration of } \mathrm{P}^{-\mathrm{PO}_{4}{ }^{3-}}[\mathrm{mg} / \mathrm{L}] \text { in } \\
\text { rainwater samples: mean }{ }^{*}(\mathrm{~min}-\mathrm{max})\end{array}$ & $0.018(0-0.274)$ & $0.012(-0.249)$ & $0.043(-0.213)$ \\
\hline $\begin{array}{l}\mathrm{UAL} \text { of } \mathrm{P}-\mathrm{PO}_{4}{ }^{3-}\left[\mathrm{mg} / \mathrm{m}^{2}\right] \text { in } \\
\text { precipitation }\end{array}$ & 8.27 & 4.00 & 23.47 \\
\hline \multicolumn{4}{|c|}{ Runoff } \\
\hline Volume of leachate [mm] & 158.7 & 119.0 & 106.8 \\
\hline $\begin{array}{l}\text { Concentration of } \mathrm{P}^{-\mathrm{PO}_{4}}{ }^{3-}[\mathrm{mg} / \mathrm{L}] \text { in } \\
\text { leachate samples: mean }{ }^{*}(\mathrm{~min}-\mathrm{max})\end{array}$ & $0.075(-0.229)$ & $0.090(-0.281)$ & $0.026(-0.223)$ \\
\hline UAL of $\mathrm{P}-\mathrm{PO}_{4}{ }^{3-}\left[\mathrm{mg} / \mathrm{m}^{2}\right.$ of substrate $]$ & 12.00 & 10.73 & 2.80 \\
\hline
\end{tabular}

Notes: * Volume-weighted mean concentration. ${ }^{* *}$ Calculated from the time of the first leachate collected to the time of the last leachate collected.

Phosphates were detected in most leachates from tested substrate in all monitored vegetation seasons (Figure 4). The range of observed $\mathrm{P}-\mathrm{PO}_{4}{ }^{3-}$ concentrations was similar in first, second, and fifth years of observation (Table 4). The volume-weighted mean concentration in runoff was higher in the second year of operation than in the first year, but in the fifth year of operation the volume-weighted mean concentration in runoff was tree times lower than observed in the first year. Despite the highest load of $\mathrm{P}_{-} \mathrm{PO}_{4}{ }^{3-}$ supplied to the model with precipitation in the fifth year of the experiment, the cumulated load of $\mathrm{P}_{-} \mathrm{PO}_{4}{ }^{3-}$ released from the substrate was four times lower than values noted in the first and second years of model monitoring. Correlation analyses were applied over all data combined to assess the relationships between phosphate concentration in leachates and the volume of precipitation, volume of leachate, and concentration of phosphates in precipitation. Only in the 
second year of the experiment, phosphate concentrations in green roof leachate were correlated with the volume of precipitation and the volume of leachate (Table 5).
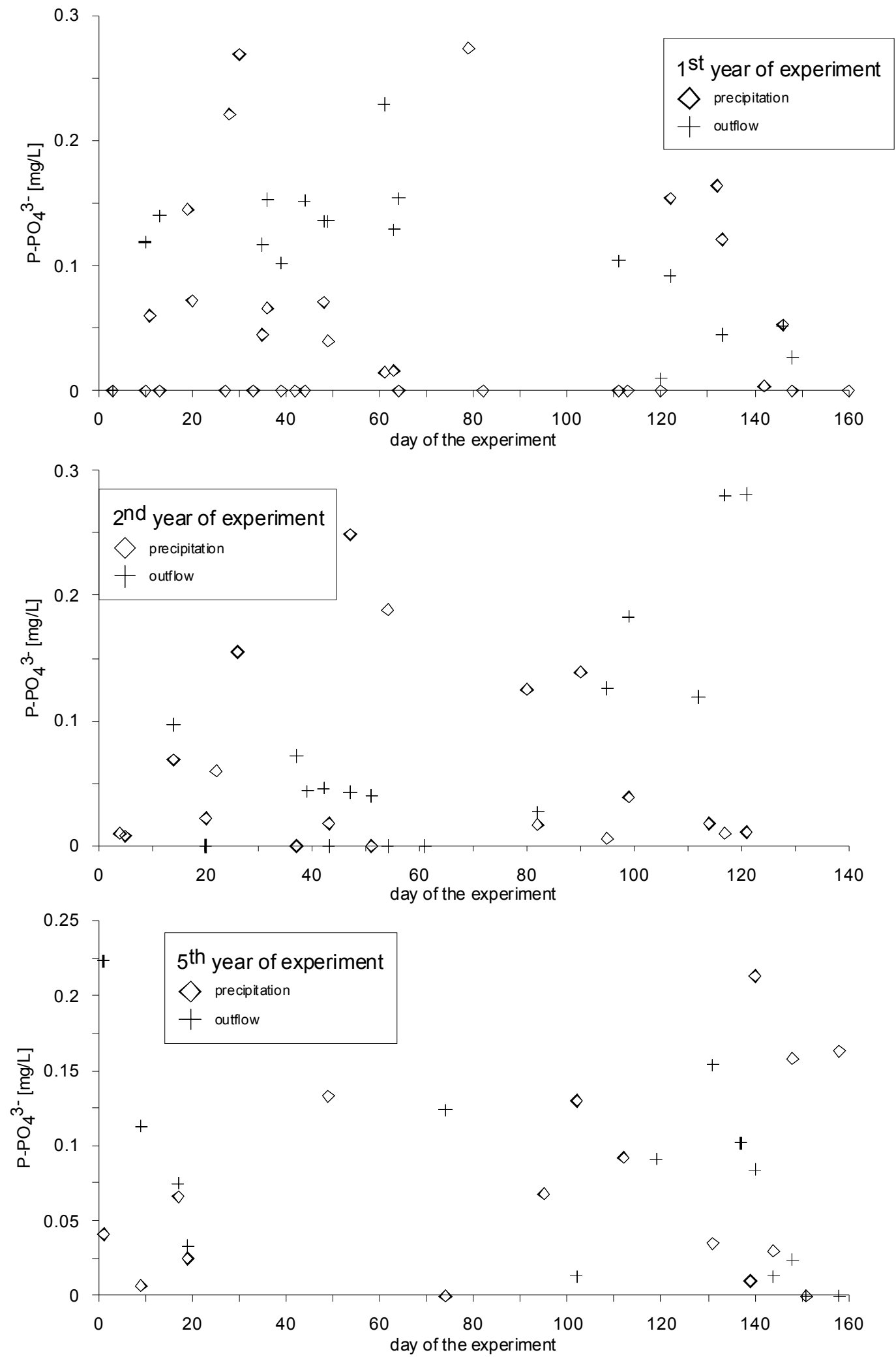

Figure 4. Concentration of $\mathrm{P}_{-} \mathrm{PO}_{4}{ }^{3-}$ in precipitation and leachates from substrate tested in long-term monitoring open air experiment. 
Table 5. Results of correlation analyses between phosphate concentration in leachates from the open air experiment in 2013, 2014, and 2017, and volumes of precipitation, volumes of leachate, and concentration of phosphates in precipitation, presented as Pearson correlation coefficient $r$ and probability $p$ (in brackets). $p$-values below 0.05 indicate statistically significant non-zero correlations at the $95.0 \%$ confidence level.

\begin{tabular}{cccc}
\hline $\begin{array}{c}\text { Phosphate Concentrations in } \\
\text { Leachate }\end{array}$ & Volume of Precipitation & Volume of Leachate & $\begin{array}{c}\text { Concentration of Phosphates } \\
\text { in Precipitation }\end{array}$ \\
\hline 2013 (1st year of experiment) & $-0.0563(0.7804)$ & $0.1011(0.6157)$ & $-0.3428(0.0801)$ \\
2014 (2nd year of experiment) & $0.4555(0.0380)$ & $0.5138(0.0172)$ & $-0.2507(0.2729)$ \\
2017 (5th year of experiment) & $-0.1551(0.0483)$ & $0.0456(0.8486)$ & $0.3622(0.1166)$ \\
\hline
\end{tabular}

\section{Discussion}

Cumulative $\mathrm{P}-\mathrm{PO}_{4}{ }^{3-}$ load released from fresh substrates tested in leaching column experiment, simulating the first vegetation period of green roof use (Table 2), accounted for only $1.74-2.41 \%$ of $\mathrm{P}$ content in substrate estimated in $\mathrm{HCl}$ extraction test (Figure 2). However, good correlation $(r=0.9930$, $p=0.002$ ) was observed between those values for all five tested fresh substrates. That suggests, that batch $\mathrm{HCl}$ extraction may be useful and recommended test for selection of substrates based on potential phosphorus leaching. However, it should be confirmed on the larger population samples of fresh green roof substrates. In this study, the correlation between leachable phosphates estimated by distilled water extraction and cumulative P loads in leachate was not significant (at $p<0.005)$.

The green roof runoff volume-weighted concentrations of $\mathrm{P}_{-} \mathrm{PO}_{4}{ }^{3-}$ observed in this study were lower in case of open air green roof model than in column leaching experiment. A similar situation was also observed by [12]. They explained, that stormwater on full scale roofs come in contact with more of the green roof surface prior to runoff. Comparing the results from column leaching experiment only, intensive substrates released $\mathrm{P}$ in higher concentrations than extensive substrates. Concentrations were higher than those reported in some studies $[15,16]$, but lower than those reported by [17]. Concentrations from open-air experiments were generally very low, comparable more to extensive substrates than intensive ones. The differences among this study and studies reported by other authors may be attributed to a variety of factors, including the composition of growing media, the type and extent of vegetative cover, fertilizer use, and the age of the roofs. The impact of the substrate age has also been confirmed in this study in the case of volume-weighted mean concentrations and UALs, but not in the observed $\mathrm{P}_{-} \mathrm{PO}_{4}{ }^{3-}$ concentrations range (Table 3). In the fifth year of the experiment the green roof acted as a net sink of phosphorus (mean runoff concentration $<$ atmospheric deposition). Roof age, followed by the summer and winter seasonal dynamics, had a greatest effect on phosphate concentrations in runoff from green roofs tested by [14]. Based on the created model, they predicted that the time, within which the green roof can act as a source of P may be as long as 11 years. Malcolm et al. [12] observed elevated P concentrations in the runoff more than three years after construction. However, still not enough long-term green roof studies have been carried out.

In terms of the impacts of green roof runoff on water bodies downstream, loads are more important than concentrations [32]. Unit area loadings (UAL), even if useful in the estimation of P-pollution from specific green roofs, are difficult to compare between studies, as the construction of green roofs (thickness of the substrate) vary in different cases. For example, [33] irrigated unplanted Arkalyte mix and GAF (Gardenscapes) substrates got similar to this study's amount of rainwater (400-500 mm). Substrates released of about 500 and $800 \mathrm{mg} \mathrm{P} / \mathrm{m}^{2}$, respectively. The information of substrate depth is not included in the cited study, but the maximum depth of Green Roof Blocks $^{\mathrm{TM}}$ is $10.16 \mathrm{~cm}$, so the thickness of the substrate itself was less than $10 \mathrm{~cm}$. In both studies fresh substrates were tested. Initial P content assessed for Arkalyte mix and GAF substrates was $60 \mathrm{mg} / \mathrm{kg}$ and $219 \mathrm{mg} / \mathrm{kg}$, respectively, so they do not differ much from the values noted in our study $(17-145 \mathrm{mg} / \mathrm{kg})$. Gregoire and Clausen [15] calculated unit area loading from extensive GreenGrid ${ }^{\circledR}$ 
media to $0.21 \mathrm{~kg} \cdot \mathrm{P}-\mathrm{PO}_{4}{ }^{3-} / \mathrm{ha} /$ year $\left(21 \mathrm{mg} \mathrm{P}-\mathrm{PO}_{4}{ }^{3-} / \mathrm{m}^{2}\right.$ year), what is the value close to obtained for extensive green roof substrate for the vegetation period in this study. UALs comparable to intensive substrates tested in this study were also reported by [8] for the substrate composed of crushed volcanic rock, compost, blonde peat, cooked clay, and washed sand.

Urban water bodies are already rich in phosphorus [34] because urban runoff and erosion are escalated by increased impervious cover. Mallin et al. [35] found mean orthophosphate concentrations of $0.0698 \mathrm{mg} / \mathrm{L}$ in creeks draining a highly-urbanized catchment, while in suburbanized catchment and rural catchment creeks orthophosphate concentrations were 0.0540 and $0.0486 \mathrm{mg} / \mathrm{L}$, respectively. Taebi and Droste [36] reported unit loads of TP in urban stormwater runoff in areas with small, mild, and high precipitation of $0.2,1.0$, and $2.0 \mathrm{~kg} / \mathrm{ha}$ /year, respectively. The load of total phosphorus discharged to the receiver from an urban stormwater system in Poland was estimated to be about $1.5 \mathrm{~kg} / \mathrm{ha}$ of sealed area [37]. The role of green roofs is to solve environmental problems, e.g., by delaying stormwater runoff, improving air quality, or mitigating the urban heat island effect, not creating new problems by supplying urban waters with nutrients. Therefore, the study of green roof components for potential phosphorus outflow is so important.

Runoff from the rooftops is transported through a sewer system or is discharged directly into a receiving water body. Phosphorus export from green roofs may be problematic in this context, as $\mathrm{P}$ is commonly the main governing factor for eutrophication of freshwater [38,39]. The loss of $P$ to urban water reservoirs can result in increased productivity of the system, and what follows, the rapid growth of algae and loss of aesthetic values. The relationship between phosphorus levels in lake water and lake clarity is well established. As the total amount of phosphorus in the water increases, the amount of algae in the water increases and the clarity of the water decreases [40]. Moreover, most algae are able to take in more phosphorus than needed during times when phosphorus levels are high and store it for later use when phosphorus levels in the water column are low [41]. An effect of phosphorus leaching from green roof substrates on urban water bodies may be attributed to a type of receiver. Reservoirs and rivers may be impacted by excess phosphorus loads, however, their response, in terms of algal blooms, may vary because of various physical factors, such as flow. A combination of a green roof with a pond, acting as a rainwater retention reservoir, is the common solution in newly-constructed residential areas. Shallow and small in volume, urban rainwater retention ponds are the most sensitive type of receiver, and may respond dramatically even to small inputs (loads) of phosphorus, resulting in excessive algae and plant growth. Phosphorus concentrations as low as $0.02-0.03 \mathrm{mg} / \mathrm{L}$ can already begin to promote blooms of algae. Significant and frequent blooms are noted as concentrations rise to $0.05-0.07 \mathrm{mg} / \mathrm{L}$ [40]. It is assumed that concentrations of $\mathrm{P}$ in pond should be kept below $0.01 \mathrm{mg} / \mathrm{L}$ to avoid algae grow [42]. It would be extremely difficult, or even impossible, to keep this level, when periodic $\mathrm{P}$ input from the green roof will occur. Moreover, observed in green roof runoff, $\mathrm{N}$ and $P$ ratios at or below the Redfield ratio, which could adversely impact downstream water quality [12].

To keep urban water bodies in high environmental and aesthetic value, limiting P inflow from all potential sources is advisable. One of measure to prevent excessive $P$ leaching from green roofs to urban receivers can be the implementation of specially-prepared low P-emission substrate [4]. Camm [43] integrated an adsorptive filter media for $\mathrm{P}$ removal to a green roof system. The evaluated media, reduced SRP loadings by $82.4 \%$ and TP loadings by $86.6 \%$, however, the effluent concentrations still exceeded values of $0.03 \mathrm{mg} / \mathrm{L}$ for TP. Beck et al. [19] obtained $43 \%$ phosphate reduction in leachate by adding 7\% biochar to bare green roof substrate. Malcolm et al. [12] implemented alum and Ultra_Phos Filter ${ }^{\circledR}$ to mitigate effects of nutrient pollution. The chosen method of application of Ultra_Phos Filter ${ }^{\circledR}$ did not reduce $\mathrm{P}$ in runoff, but alum reduced $\mathrm{P}$ by approximately $20 \%$ in runoff. Another option to mitigate runoff of phosphorus is to underline the substrate with P-reactive drainage material [44-46]. Construction of green roofs without any $\mathrm{P}$ release protection measure can strongly contribute to eutrophication of urban water bodies. To make green roof technology more sustainable at least one $P$ reduction measures should be implemented. Those measures are: (i) selection of the substrate 
mix with limited P content and release potential [4]; (ii) underlying the substrate with the P reactive material [44-46]; or (iii) implementation of a P-reactive filtration system to treat green roof runoff [47].

\section{Conclusions}

Results of performed experiments confirmed, that green roof substrates are a significant source of phosphorus in runoff. Batch $\mathrm{HCl}$ extraction test is recommended for the comparison and selection of substrates with low potential phosphorus leaching. Volume-weighted mean concentrations and UALs of $\mathrm{P}_{-} \mathrm{PO}_{4}{ }^{3-}$ in leachates from fresh substrates were higher in case of intensive substrates, but there was no clear relationship between the substrate type and the observed $\mathrm{P}_{-} \mathrm{PO}_{4}{ }^{3-}$ concentration range. This study also confirmed that substrate age influenced the volume-weighted mean $\mathrm{P}_{-} \mathrm{PO}_{4}{ }^{3-}$ concentrations and UAL was calculated based on the data from the vegetation period, but did not influence $\mathrm{P}_{-} \mathrm{PO}_{4}{ }^{3-}$ concentrations range found in the outflow.

Acknowledgments: Research equipment used in this study belongs to Laboratory of Ecotechnology and Laboratory of Irrigation and Drainage, Water Center SGGW.

Author Contributions: Agnieszka Karczmarczyk designed the concept of the work, took part in construction of column experiment, sampling and analysis form column and long-term model experiment, performed the extraction tests of substrates, analyzed the data, created a figures and wrote the manuscript; Anna Baryła performed statistical analyses, performed the tests of physical characteristics of substrates, constructed green roof container tested in long-term experiments, as well took part in sampling of rainwater and leachate from the model; and Agnieszka Bus took part in construction of column experiment, sampling, and analysis and edition of the final version of the manuscript.

Conflicts of Interest: The authors declare no conflict of interest.

\section{References}

1. Wang, H.; Qin, J.; Hu, Y. Are green roofs a source or sink of runoff pollutants? Ecol. Eng. 2017, 107, 65-70. [CrossRef]

2. John, J.; Kernaghan, G.; Lundholm, J. The potential for mycorrhizae to improve green roof function. Urban Ecosyst. 2017, 20, 113-127. [CrossRef]

3. Berndtsson, J.C. Green roof performance towards management of runoff water quantity and quality. Ecol. Eng. 2010, 36, 351-360. [CrossRef]

4. Karczmarczyk, A.; Baryła, A.; Kożuchowski, P. Design and development of low P-emission substrate for the protection of urban water bodies collecting green roof runoff. Sustainability 2017, 9, 1795. [CrossRef]

5. Buffam, I.; Mitchell, M.E. Nutrient cycling in green roof ecosystems. In Green Roofs Ecosystems; Sutton, R., Ed.; Springer: New York, NY, USA, 2015; Volume 223, pp. 107-137.

6. Toland, D.C.; Haggard, B.E.; Boyer, M.E. Evaluation of nutrient concentrations in runoff water from green roofs, conventional roofs, and urban streams. Trans. ASABE 2012, 55, 99-106. [CrossRef]

7. Czemiel Berndtsson, J.; Bengtsson, L.; Jinno, K. Runoff water quality from intensive and extensive vegetated roofs. Ecol. Eng. 2009, 35, 369-380. [CrossRef]

8. Van Seters, T.; Rocha, L.; Smith, D.; MacMillan, G. Evaluation of green roofs for runoff retention, runoff quality, and leachability. Water Qual. Res. J. Can. 2009, 44, 33-47.

9. Rowe, D.B. Green roofs as a means of pollution abatement. Environ. Pollut. 2011, 159, 2100-2110. [CrossRef] [PubMed]

10. Nagase, A.; Dunnett, N. The relationship between percentage of organic matter in substrate and plant growth in extensive green roofs. Landsc. Urban Plan. 2011, 103, 230-236. [CrossRef]

11. Emilsson, T. Vegetation developement on extensive vegetated green roofs: Influence of substrate composition, estabilishment method and species mix. Ecol. Eng. 2008, 33, 265-277. [CrossRef]

12. Malcolm, E.G.; Reese, M.L.; Schaus, M.H.; Ozmon, I.M.; Tran, L.M. Measurements of nutrients and mercury in green roof and gravel roof runoff. Ecol. Eng. 2014, 73, 705-712. [CrossRef]

13. Berndtsson, J.C.; Emilsson, T.; Bengtsson, L. The influence of extensive vegetated roofs on runoff water quality. Sci. Total Environ. 2006, 355, 48-63. [CrossRef] [PubMed]

14. Mitchell, M.E.; Matter, S.F.; Durtsche, R.D.; Buffam, I. Elevated phoshorus: Dynamics during four years of green roof development. Urban Ecosyst. 2017, 20, 1121-1133. [CrossRef] 
15. Gregoire, B.G.; Clausen, J.C. Effect of modular extensive green roof on stormwater runoff and water quality. Ecol. Eng. 2011, 37, 963-969. [CrossRef]

16. Teemusk, A.; Mander, Ü. The Influence of Green Roofs on Runoff Water Quality: A Case Study from Estonia. Water Resour Manag. 2011, 25, 3699-3713. [CrossRef]

17. Aitkenhead-Peterson, J.; Dvorak, B.D.; Volder, A.; Stanley, N.C. Chemistry of growth medium and leachate from green roof systems in south-central Texas. Urban Ecosyst. 2011, 14, 17-33. [CrossRef]

18. Aloisio, J.M.; Tuininga, A.R.; Lewis, J.D. Crop species selection effects on stormwater runoff and edible biomass in an agricultural green roof microcosm. Ecol. Eng. 2016, 88, 20-27. [CrossRef]

19. Beck, D.A.; Johnson, G.R.; Spolek, G.A. Amending greenroof soil with biochar to affect runoff water quantity and quality. Environ. Pollut. 2011, 159, 2111-2118. [CrossRef] [PubMed]

20. Seidl, M.; Gromaire, M.-C.; Saad, M.; De Gouvello, B. Effect of substrate depth and rain-event history on the pollutant abadement of green roofs. Environ. Pollut. 2013, 183, 195-203. [CrossRef] [PubMed]

21. Vijayaraghavan, K.; Joshi, U.M.; Balasubramanian, R. A field study to evaluate runoff quality from green roofs. Water Res. 2012, 46, 1337-1345. [CrossRef] [PubMed]

22. Burszta-Adamiak, E. Analysis of stormwater retention on green roofs. Arch. Environ. Prot. 2012, 38, 3-13.

23. Valentukevičienè, M.; Rynkun, G. Water reuse possibilities at students dormitories. Annu. Set Environ. Prot. 2016, 18, 927-936.

24. Dusza, Y.; Barot, S.; Kraepiel, Y.; Lata, J.C.; Abbadie, L.; Raynaud, X. Multifunctionality is affected by interactions between green roof plant species, substrate depth, and substrate type. Ecol. Evol. 2017, 7, 2357-2369. [CrossRef] [PubMed]

25. Nagase, A.; Dunnett, N.; Choi, M.S. Investigation of plant growth and flower performance on a semi-extensive green roof. Urban For. Urban Green. 2017, 23, 61-73. [CrossRef]

26. Forschungsgesellschaft Landschaftsentwicklung Landschaftsbau (FLL). Guidelines for the Planning, Construction and Maintenance of Green Roofing_Green Roofing Guideline; FLL: Bonn, Germany, 2008.

27. Stowarzyszenie Wykonawców Dachów Płaskich i Fasad (DAFA). Dachy zielone. In Wytyczne do Projektowania, Wykonywania i Pielegnacji Dachów Zielonych-Wytyczne dla Dachów Zielonych; Stowarzyszenie Wykonawców Dachów Płaskich i Fasad (DAFA): Opole, Poland, 2015.

28. International Organization for Standardization (ISO). PN-ISO 10390:1997 Equivalent to ISO 10390:1994 Soil Quality-Determination of $p H$; ISO: Geneva, Switzerland, 1998.

29. Ascott, M.J.; Gooddy, D.C.; Lapworth, D.J.; Stuart, M.E. Estimating the leakage contribution of phosphate dosed drinking water to environmental phosphorus pollution at the national-scale. Sci. Total Environ. 2016, 572, 1534-1542. [CrossRef] [PubMed]

30. Felipe, M.J.; Nguen, K.; Guo, B.B.; Sandu, C.; Fulmer, D.; Baker, H. Non-phosphorus corrosion inhibitor optimizes cooling tower uptime for environmental compliance. Hydrocarb. Process. 2016, 95, 73-76.

31. Valentukevičienè, M.; Zurauskiene, R.; Satkunas, J. The main microelements and phosphorus content of sediments formed in a drinking water supply system. Estonian J. Earth Sci. 2016, 65, 248-257. [CrossRef]

32. Kuoppamäki, K.; Lehvävirta, S. Mitigating nutrient leaching from green roofs with biochar. Landsc. Urban Plan. 2016, 152, 39-48. [CrossRef]

33. Harper, G.E.; Limmer, M.A.; Showalter, W.E.; Burken, J.G. Nine-month evaluation of runoff quality and quantity from an experimental green roof in Missouri, USA. Ecol. Eng. 2015, 78, 127-133. [CrossRef]

34. Song, K.; Xenopoulos, M.A.; Marsalek, J.; Frost, P.C. The fingerprints of urban nutrients: Dynamics of phosphorus speciation in water flowing through developed landscapes. Biogeochemistry 2015, 125, 1-10. [CrossRef]

35. Mallin, A.M.; Johnson, V.L.; Ensign, S.H. Comparative impacts of stormwater runoff on water quality of an urban, a suburban, and a rural stream. Environ. Monit. Assess. 2009, 159, 475-491. [CrossRef] [PubMed]

36. Taebi, A.; Droste, R.L. Pollution loads in urban runoff and sanitary watewater. Sci. Total Environ. 2004, 327, 175-184. [CrossRef] [PubMed]

37. Pluta, K.; Mrowiec, M. Analiza oddziaływania systemów kanalizacyjnych na odbiornik. Inż. Ekol. 2015, 45, 183-194. [CrossRef]

38. Gajewska, M.; Obarska-Pempkowiak, H. Efficiency of pollutant removal by five multistage constructed wetlands in a temperate climate. Environ. Prot. Eng. 2011, 37, 27-36.

39. Gajewska, M.; Kopeć, Ł.; Obarska-Pempkowiak, H. Operation of small wastewater treatment facilities in a scattered settlement. Rocz. Ochr. Środowiska 2011, 13, 207-225. 
40. Spetzman, J.; Black, G.; Hetzel, C.; McDonald, K.; Heiskary, S.; Horgan, B.; Mugaas, B.; Rosen, C.; Struss, R. Phosphorus in Lawns, Landscapes and Lakes. In An Informative Guide on Phosphorus; Minnesota Department of Agriculture, Minnesota Office of Environmental Assistance, Minnesota Pollution Control Agency, University of Minnesota Extension Service: St Paul, MN, USA, 2004.

41. Walker, J.L.; Younos, T.; Zipper, C.E. Nutrients in Lakes and Reservoirs-A Literature Review for Use in Nutrient Criteria Development; Report Grant No. 06HQGR0021; Virginia Polytechnic Institute and State University Blacksburg: Blacksburg, VA, USA, 2007.

42. Forschungsgesellschaft Landschaftsentwicklung Landschaftsbau (FLL). Recommendations for Planning, Construction, Servicing and Operation of Outdoor Swimming Pools with Biological Water Purification (Swimming and Bathing Ponds); FLL: Bonn, Germany, 2013.

43. Camm, E. An Evaluation of Engineered Media for Phosphorus Removal from Greenroof Stormwater Runoff. Master's Thesis, University of Waterloo, Waterloo, ON, Canada, 2011.

44. Karczmarczyk, A.; Baryła, A.; Bus, A. Effect of P-reactive drainage aggregates on green roof runoff quality. Water 2014, 6, 2575-2589. [CrossRef]

45. Bus, A.; Karczmarczyk, A.; Baryła, A. The use of reactive material for limiting P-leaching from green roof substrate. Water Sci. Technol. 2016, 73, 3027-3032. [CrossRef] [PubMed]

46. Karczmarczyk, A.; Kocik, A. Influence of the thickness of the P-reactive drainage layer on phosphate content in green roof runoff. Sci. Rev. Eng. Environ. Sci. 2017, 26, 448-457. (In Polish)

47. Karczmarczyk, A.; Bus, A. Removal of phosphorus using suspended reactive filters (SRFs)—Efficiency and potential applications. Water Sci. Technol. 2017, 76, 1104-1111. [CrossRef] [PubMed]

(C) 2018 by the authors. Licensee MDPI, Basel, Switzerland. This article is an open access article distributed under the terms and conditions of the Creative Commons Attribution (CC BY) license (http:/ / creativecommons.org/licenses/by/4.0/). 